\title{
Seasonal variation of the ozone production efficiency per unit NOx at Harvard Forest, Massachusetts
}

\section{Citation}

Hirsch, Adam I., J. William Munger, Daniel J. Jacob, Larry W. Horowitz, and Allen H. Goldstein. 1996. "Seasonal Variation of the Ozone Production Efficiency Per Unit NOx at Harvard Forest, Massachusetts." Journal of Geophysical Research 101 (D7): 12659. doi:10.1029/96jd00557.

\section{Published Version}

doi:10.1029/96JD00557

\section{Permanent link}

http://nrs.harvard.edu/urn-3:HUL.InstRepos:14121818

\section{Terms of Use}

This article was downloaded from Harvard University's DASH repository, and is made available under the terms and conditions applicable to Other Posted Material, as set forth at http:// nrs.harvard.edu/urn-3:HUL.InstRepos:dash.current.terms-of-use\#LAA

\section{Share Your Story}

The Harvard community has made this article openly available.

Please share how this access benefits you. Submit a story.

\section{Accessibility}




\title{
Seasonal variation of the ozone production efficiency per unit $\mathrm{NO}_{\mathrm{x}}$ at Harvard Forest, Massachusetts
}

\author{
Adam I. Hirsch, ${ }^{1}$ J. William Munger, Daniel J. Jacob, \\ Larry W. Horowitz, and Allen H. Goldstein ${ }^{2}$ \\ Division of Applied Sciences and Department of Earth and Planetary Sciences, Harvard University, \\ Cambridge, Massachusetts
}

\begin{abstract}
Weekly values of the net $\mathrm{O}_{3}$ production efficiency (OPE), defined as the net number of $\mathrm{O}_{3}$ molecules produced per molecule of $\mathrm{NO}_{x}\left(\mathrm{NO}+\mathrm{NO}_{2}\right)$ consumed, are estimated from a 1990-1994 record of $\mathrm{O}_{3}, \mathrm{NO}_{x}, \mathrm{NO}_{y}, \mathrm{CO}$, and $\mathrm{C}_{2} \mathrm{H}_{2}$ concentrations at Harvard Forest, Massachusetts. The OPE is inferred from the slope $\Delta \mathrm{O}_{3} / \Delta\left(\mathrm{NO}_{\mathrm{y}}-\mathrm{NO}_{\mathrm{x}}\right)$ of the linear regression between $\mathrm{O}_{3}$ and $\mathrm{NO}_{y}-\mathrm{NO}_{\mathrm{x}}$ concentrations $\left(\mathrm{NO}_{\mathrm{y}}\right.$ is the sum of $\mathrm{NO}_{\mathrm{x}}$ and its oxidation products); and alternatively from the slopes $\Delta \mathrm{O}_{3} / \Delta \mathrm{CO}$ and $\Delta \mathrm{O}_{3} / \Delta \mathrm{C}_{2} \mathrm{H}_{2}$ multiplied by regional estimates of the $\mathrm{CO} / \mathrm{NO}_{\mathrm{x}}$ and $\mathrm{C}_{2} \mathrm{H}_{2} / \mathrm{NO}_{\mathrm{x}}$ emission ratios. The mean OPE values inferred from $\Delta \mathrm{O}_{3} / \Delta\left(\mathrm{NO}_{\mathrm{y}}-\mathrm{NO}_{\mathrm{x}}\right)$ are 3-5 times higher than those inferred from $\Delta \mathrm{O}_{3} / \Delta \mathrm{CO}$ or $\Delta \mathrm{O}_{3} / \Delta \mathrm{C}_{2} \mathrm{H}_{2}$; the discrepancy may be due to the effects of $\mathrm{HNO}_{3}$ and $\mathrm{O}_{3}$ deposition and also to uncertainties in the $\mathrm{CO} / \mathrm{NO}_{\mathrm{x}}$ and $\mathrm{C}_{2} \mathrm{H}_{2} / \mathrm{NO}_{x}$ emission ratios. The relative seasonal trends of the OPE derived from $\Delta \mathrm{O}_{3} / \Delta\left(\mathrm{NO}_{\mathrm{y}}-\mathrm{NO}_{\mathrm{x}}\right), \Delta \mathrm{O}_{3} / \Delta \mathrm{CO}$, and $\Delta \mathrm{O}_{3} / \Delta \mathrm{C}_{2} \mathrm{H}_{2}$ are, however, similar. Thus $\Delta \mathrm{O}_{3} / \Delta\left(\mathrm{NO}_{\mathrm{y}}-\mathrm{NO}_{\mathrm{x}}\right)$ increases from about $4 \mathrm{~mol} / \mathrm{mol}$ in May to $8 \mathrm{~mol} / \mathrm{mol}$ in June-July, and gradually decreases back to $4 \mathrm{~mol} / \mathrm{mol}$ by early October. The sharp rise of the OPE from May to June is attributed to onset of emission of the biogenic hydrocarbon isoprene. The decline from July to October is attributed to decreases in isoprene emission and in solar radiation. The $\mathrm{O}_{3}$ background at Harvard Forest, defined by the $y$ intercept of the $\mathrm{O}_{3}$ versus $\mathrm{NO}_{\mathrm{y}}-\mathrm{NO}_{\mathrm{x}}$ regression line, decreases from 40 ppbv in May to $25 \mathrm{ppbv}$ in September, consistent with observations at remote sites in northern midlatitudes. The seasonal trend in the background explains why mean $\mathrm{O}_{3}$ concentrations at Harvard Forest peak in May-June even though the OPE pcaks in June-July.
\end{abstract}

\section{Introduction}

Rapid production of $\mathrm{O}_{3}$ takes place over the United States in summer by photochemical oxidation of hydrocarbons in the presence of nitrogen oxides $\left(\mathrm{NO}_{\mathrm{x}}=\mathrm{NO}+\mathrm{NO}_{2}\right)$. Concentrations of $\mathrm{O}_{3}$ in surface air are sufficiently high to have adverse effects on public health and vegetation [National Research Council, 1991]. It is well established that $\mathrm{NO}_{x}$ is in general the principal limiting precursor for $\mathrm{O}_{3}$ formation [Chameides et al., 1992], but there is much uncertainty regarding the factors controlling the $\mathrm{O}_{3}$ yield per unit $\mathrm{NO}_{\mathbf{x}}\left(\mathrm{O}_{3}\right.$ production efficiency, or OPE). We address this issue here by analysis of a long-term record of observations at Harvard Forest, Massachusetts.

The OPE concept was originally introduced by Liu et al. [1987] as the number of $\mathrm{O}_{3}$ molecules produced per molecule of $\mathrm{NO}_{\mathbf{x}}$ oxidized. One may define either a gross OPE or a nel OPE, based on consideration of either the total or the net number of $\mathrm{O}_{3}$

${ }^{1}$ Now at Department of Geoscience, University of California at Irvine.

2 Now at Department of Environmental Science, Policy, and Management, University of California at Berkeley.

Copyright 1996 by the American Geophysical Union.

Paper number 96JD00557.

0148-0227/96/96JD-00557\$09.00 molecules produced [Lin et al., 1988]. The OPE is a useful quantity for scaling $\mathrm{O}_{3}$ production on a regional scale to the amount of $\mathrm{NO}_{x}$ emitted, and also for measuring the chemical efficiency of $\mathrm{O}_{3}$ production in a way that normalizes to $\mathrm{NO}_{\mathrm{x}}$ emission and is not directly dependent on transport considerations. Photochemical models suggest that the OPE should decrease with increasing $\mathrm{NO}_{\mathrm{x}}$, increase with increasing hydrocarbons and UV flux, and be relatively insensitive to temperature or humidity [Liu et al., 1987; Lin et al., 1988; Sillman et al., 1990; Walcek and Yuan, 1995]. Our analysis offers a test of these models as well as some new insights for understanding the seasonal variation of $\mathrm{O}_{3}$ concentrations over the eastern United States.

\section{Methods}

Harvard Forest is a wooded tract in the town of Petersham in central Massachusetts $\left(42^{\circ} 32^{\prime} \mathrm{N}, 72^{\circ} 11^{\prime} \mathrm{W}\right)$. The surrounding area is forested and rural. The nearest large cities are Boston and Hartford, $100 \mathrm{~km}$ to the east and southwest respectively. New York City is $250 \mathrm{~km}$ to the $\mathrm{SW}$. Continuous measurement of trace gases at Harvard Forest has been conducted since 1990 from a $30-\mathrm{m}$ tower extending $6 \mathrm{~m}$ above the forest canopy. The measurements include concentrations of $\mathrm{O}_{3}, \mathrm{NO}_{\mathrm{x}}, \mathrm{NO}_{\mathrm{y}}$ (sum of $\mathrm{NO}_{\mathrm{x}}$ and its oxidation products), $\mathrm{CO}$, and hydrocarbons [Munger et al., 1996; Goldstein et al., 1995]. High concentrations are associated with surface winds from the $\mathrm{SW}$, indicating advection of regional 
Table 1. Data Selection for Calculating $\Delta \mathrm{O}_{3} / \Delta\left(\mathrm{NO}_{\mathrm{y}}-\mathrm{NO}_{\mathrm{x}}\right)$ at Harvard Forest

\begin{tabular}{lcccc}
\hline Month & $\begin{array}{c}\text { Critcrion } 1 \\
n>10\end{array}$ & $\begin{array}{c}\text { Criterion 2 } \\
{\left[\mathrm{O}_{3}\right]_{\max }>50 \mathrm{ppbv}}\end{array}$ & $\begin{array}{c}\text { Criterion } 3 \\
r^{2}>0.5\end{array}$ & $\begin{array}{c}\text { Criterion 4 } \\
{\left[\mathrm{O}_{3}\right]_{\text {background }}<50 \text { ppbv }}\end{array}$ \\
\hline Jan. & 6 & 0 & 0 & 0 \\
Feb. & 5 & 0 & 0 & 0 \\
Mar. & 7 & 6 & 0 & 0 \\
April & 10 & 10 & 0 & 0 \\
May & 13 & 13 & 7 & 6 \\
June & 13 & 13 & 8 & 8 \\
July & 8 & 8 & 6 & 6 \\
Aug. & 11 & 8 & 7 & 7 \\
Sept. & 10 & 6 & 6 & 6 \\
Oct. & 11 & 3 & 3 & 3 \\
Nov. & 4 & 0 & 0 & 0 \\
Dec. & 0 & 0 & 0 & 0 \\
\hline
\end{tabular}

Number of individual weeks in the Harvard Forest record (1990-1994) satisfying each successive criterion required for calculating $\Delta \mathrm{O}_{3} / \Delta\left(\mathrm{NO}_{\mathrm{y}}-\mathrm{NO}_{\mathrm{x}}\right)$. Here $n$ is the number of concurrent hourly observations for $\mathrm{O}_{3}, \mathrm{NO}_{\mathrm{x}}$, and $\mathrm{NO}_{\mathrm{y}}$ available between 1100 and 1700 local time for a given week; $\left[\mathrm{O}_{3}\right]_{\max }$ is the maximum concentration for the week; and $r^{2}$ and $\left[\mathrm{O}_{3}\right]_{\text {background }}$ are, respectively, the linear correlation coefficient and the $y$ intercept of the $\mathrm{O}_{3}$ versus $\mathrm{NO}_{\mathrm{y}}-\mathrm{NO}_{\mathrm{x}}$ correlation.

pollution from the eastern United States with varying additions of urban plumes from New York City and Connecticut [Munger et al., 1996].

We estimate the net OPE from the Harvard Forest data on a weekly basis as the slope $\Delta \mathrm{O}_{3} / \Delta\left(\mathrm{NO}_{\mathrm{y}}-\mathrm{NO}_{\mathrm{x}}\right)$ of the linear regression between $\mathrm{O}_{3}$ and $\mathrm{NO}_{y}-\mathrm{NO}_{x}$ concentrations. Here $\Delta \mathrm{O}_{3}$ represents the enhancement of $\mathrm{O}_{3}$ over the background, $\Delta\left(\mathrm{NO}_{\mathbf{y}}-\mathrm{NO}_{\mathbf{x}}\right)$ represents the corresponding amount of $\mathrm{NO}_{\mathbf{x}}$ oxidized, and the ratio thus yields an estimate of the net OPE (from now on we will understand "OPE" to represent the net quantity). The estimate is an upper limit because of $\mathrm{HNO}_{3}$ deposition, as discussed below. The linear regression is computed with the reduced-major-axis method [Hirsch and Gilroy, 1984] applied to the hourly $\mathrm{O}_{3}$ and $\mathrm{NO}_{\mathrm{y}}-\mathrm{NO}_{\mathrm{x}}$ concentrations measured at 1100-1700 eastern standard time (EST); this time window is the period of maximum vertical mixing, when concentrations measured at the tower are most likely to be representative of the continental boundary layer. Concentrations of $\mathrm{O}_{3}$ at Harvard Forest are at their diel maximum at 1100-1700 EST, while concentrations of $\mathrm{NO}_{x}$ and $\mathrm{NO}_{\mathrm{y}}$ are at their diel minimum [Munger et al., 1996].

Our analysis covers the period from April 27, 1990 to August 31,1994 . For a given week, we calculate $\Delta \mathrm{O}_{3} / \Delta\left(\mathrm{NO}_{\mathrm{y}}-\mathrm{NO}_{\mathrm{x}}\right)$ only if four criteria are satisfied. First, concurrent observations of $\mathrm{O}_{3}$, $\mathrm{NO}_{\mathrm{x}}$, and $\mathrm{NO}_{\mathrm{y}}$ must be available for at least 10 hourly periods; this criterion limits the analysis to 98 weeks. Second, $\mathrm{O}_{3}$ concentrations must exceed 50 parts per billion by volume (ppbv) at least once during the week, to limit the effect of variability in $\mathrm{O}_{3}$ background on the slope of the regression line; this criterion excludes 31 of the 98 weeks. Third, the least-squares correlation coefficient $\left(r^{2}\right)$ between $\mathrm{O}_{3}$ and $\mathrm{NO}_{\mathrm{y}}-\mathrm{NO}_{\mathrm{x}}$ concentrations must be higher than 0.5; this criterion excludes 30 of the remaining 67 weeks (most of the excluded weeks had peak $\mathrm{O}_{3}$ values barely above 50 ppbv). Fourth, the $y$ intercept of the regression line $\left(\mathrm{O}_{3}\right.$ background) must be less than 50 ppbv, to screen periods when strong subsidence events with high $\mathrm{O}_{3}$ and low $\mathrm{NO}_{y}$ affected the correla- tion. This criterion excludes one additional week in May.

A month-by-month summary of the data selection is given in Table 1. The requirement of a weckly maximum $\mathrm{O}_{3}$ higher than 50 ppbv eliminates all weeks in November-February. The requirement of $r^{2}>0.5$ eliminates a large number of weeks in the spring, but few in summer and none in fall; this result is due to a high $\mathrm{O}_{3}$ background in spring, as discussed below. Our database of OPE values is thus limited to the May-October time window. The OPE values from November to April are certainly lower than in MayOctober, and possibly negative [Parrish, 1993], but cannot be quantified here.

For the 36 weeks where $\Delta \mathrm{O}_{3} / \Delta\left(\mathrm{NO}_{\mathrm{y}}-\mathrm{NO}_{\mathrm{x}}\right)$ values were calcu-

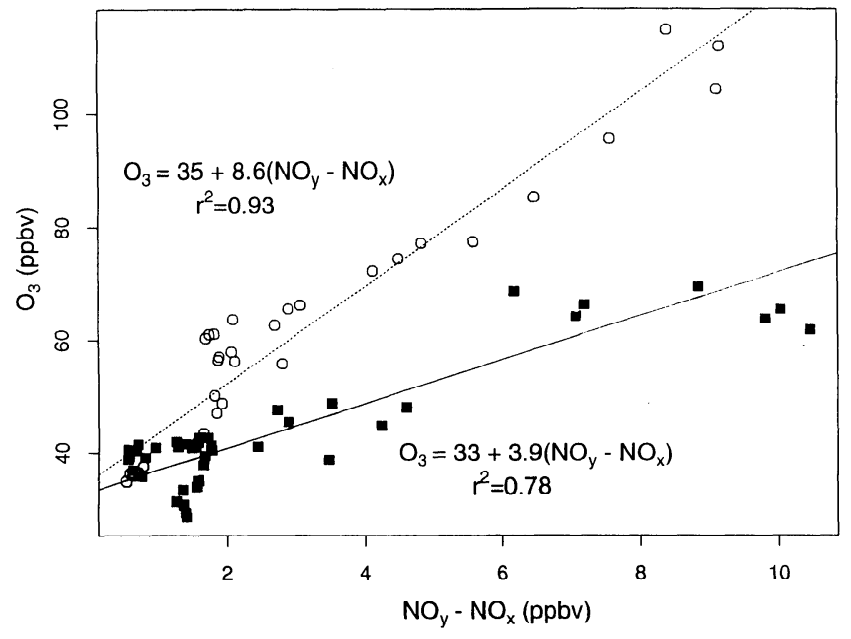

Figure 1. Scatterplots and linear regressions (reduced-major-axis method) of $\mathrm{O}_{3}$ versus $\mathrm{NO}_{y}-\mathrm{NO}_{x}$ concentrations at Harvard Forest, Massachusetts, for the weeks of May 6-12, 1990 (squares, solid line) and August 24-30, 1992 (circles, dotted line). Concentrations are hourly means at 1100-1700 EST. 

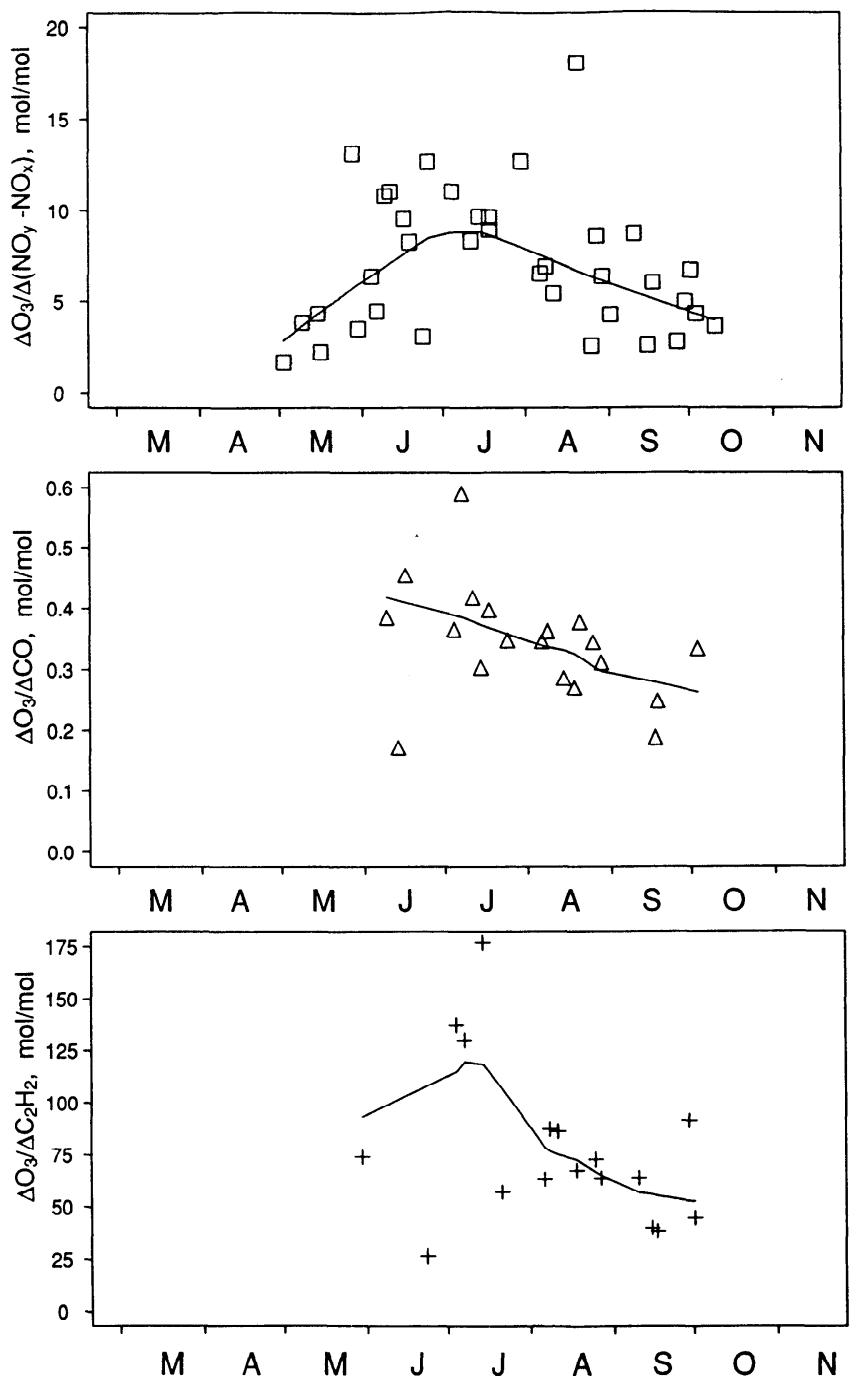

Figure 2. Enhancement ratios $\Delta \mathrm{O}_{3} / \Delta\left(\mathrm{NO}_{\mathrm{y}}-\mathrm{NO}_{\mathrm{x}}\right), \Delta \mathrm{O}_{3} / \Delta \mathrm{CO}$, and $\Delta \mathrm{O}_{3} / \Delta \mathrm{C}_{2} \mathrm{H}_{2}$ at Harvard Forest, as a function of time of year. Values for individual weeks are shown as symbols. The lines are locally weighted regressions.

lated, $r^{2}$ ranged from 0.51 to 0.97 with a median value of 0.78 . The slope $\Delta \mathrm{O}_{3} / \Delta\left(\mathrm{NO}_{\mathrm{y}}-\mathrm{NO}_{\mathrm{x}}\right)$ ranged from 2 to $18 \mathrm{~mol} / \mathrm{mol}$. The mean $y$ intercept $\left(\mathrm{O}_{3}\right.$ background) was $31 \pm 8(1 \sigma) \mathrm{ppbv}_{3}$. Two representative scatterplots are shown in Figure 1.

Interpretation of $\Delta \mathrm{O}_{3} / \Delta\left(\mathrm{NO}_{y}-\mathrm{NO}_{x}\right)$ as the net OPE is subject to uncertainties related to the deposition of $\mathrm{NO}_{y}$ and $\mathrm{O}_{3}$ and the speciation of $\mathrm{NO}_{\mathbf{y}}-\mathrm{NO}_{\mathbf{x}}$. Data presented by Parrish et al. [1993a] for rural sites in the eastern United States in summer indicate that $\mathrm{HNO}_{3}$ accounts on average for about $40 \%$ of $\mathrm{NO}_{y}-\mathrm{NO}_{x}$ during daytime, peroxyacetylnitrate (PAN) for $30 \%$, and aerosol nitrate for $10 \%$; the $20 \%$ residual may represent organic nitrates other than PAN but is also within the uncertainty of the measurements. Nitric acid is removed by wet and dry deposition on a timescale of a few days, while $\mathrm{O}_{3}$ is removed by dry deposition on a timescale of a week [Jacob et al., 1993]. The dry deposition velocity of $\mathrm{NO}_{\mathrm{y}}-\mathrm{NO}_{\mathrm{x}}$ at Harvard Forest is about twice that of $\mathrm{O}_{3}$ [Munger et al., 1996]. We expect therefore $\Delta \mathrm{O}_{3} / \Delta\left(\mathrm{NO}_{\mathrm{y}}-\mathrm{NO}_{\mathrm{x}}\right)$ to overestimate the actual OPE.

An alternate approach for estimating the OPE is to use the $\Delta \mathrm{O}_{3} / \Delta \mathrm{CO}$ and $\Delta \mathrm{O}_{3} / \Delta \mathrm{C}_{2} \mathrm{H}_{2}$ ratios derived from the $\mathrm{O}_{3}$ versus $\mathrm{CO}$ and $\mathrm{O}_{3}$ versus $\mathrm{C}_{2} \mathrm{H}_{2}$ correlations. These ratios, when scaled to $\mathrm{NO}_{\mathrm{x}} / \mathrm{CO}$ or $\mathrm{NO}_{\mathrm{x}} / \mathrm{C}_{2} \mathrm{H}_{2}$ source ratios and applied to aged air (low
$\mathrm{NO}_{\mathrm{x}} / \mathrm{NO}_{\mathrm{y}}$ concentration ratio), offer estimates of the OPE that are unaffected by speciation or deposition of $\mathrm{NO}_{\mathrm{y}}-\mathrm{NO}_{\mathrm{x}}$. The estimates are, however, lower limits because of $\mathrm{O}_{3}$ deposition and because of nonzero $\mathrm{NO}_{x} / \mathrm{NO}_{y}$; they are, in addition, affected by variability and uncertainty in the source ratios. We calculated weekly values of $\Delta \mathrm{O}_{3} / \Delta \mathrm{CO}$ and $\Delta \mathrm{O}_{3} / \Delta \mathrm{C}_{2} \mathrm{H}_{2}$ at Harvard Forest from the hourly $\mathrm{O}_{3}, \mathrm{CO}$, and $\mathrm{C}_{2} \mathrm{H}_{2}$ data at 1100-1700 EST, for those weeks satisfying the four criteria given above. The analysis was restricted to hourly periods with $\mathrm{NO}_{x} / \mathrm{NO}_{y}<0.3 \mathrm{~mol} / \mathrm{mol}$, to exclude fresh pollution plumes where $\mathrm{NO}_{\mathrm{x}}$ has not yet realized its $\mathrm{O}_{3}$ production potential [Chin et al., 1994]. We did not exclude periods when $\mathrm{NO}_{\mathrm{x}}$ or $\mathrm{NO}_{\mathrm{y}}$ data were missing as too many weeks would be affected; in those cases, we relied on the $r^{2}>0.5$ criterion to screen weeks significantly affected by fresh pollution. Values of $\Delta \mathrm{O}_{3} / \Delta \mathrm{CO}$ and $\Delta \mathrm{O}_{3} / \Delta \mathrm{C}_{2} \mathrm{H}_{2}$ were obtained for a total of 19 and 17 weeks, respectively, covering the period June-September.

\section{Results}

Figure 2 shows the seasonal variations of $\Delta \mathrm{O}_{3} / \Delta\left(\mathrm{NO}_{\mathrm{y}}-\mathrm{NO}_{\mathrm{x}}\right)$, $\Delta \mathrm{O}_{3} / \Delta \mathrm{CO}$, and $\Delta \mathrm{O}_{3} / \Delta \mathrm{C}_{2} \mathrm{H}_{2}$ in the 1990-1994 data at Harvard Forest. Figure 3 shows the corresponding seasonal variations of concentrations of $\mathrm{O}_{3}, \mathrm{NO}_{x}, \mathrm{NO}_{y}, \mathrm{CO}$, and $\mathrm{C}_{2} \mathrm{H}_{2}$, temperature, and absolute humidity. The mean value of $\Delta \mathrm{O}_{3} / \Delta\left(\mathrm{NOy}-\mathrm{NO}_{\mathrm{x}}\right)$ increases from about $4 \mathrm{~mol} / \mathrm{mol}$ in May to $8 \mathrm{~mol} / \mathrm{mol}$ in June-July, and then decreases gradually to $4 \mathrm{~mol} / \mathrm{mol}$ by early October. Previous summer data reported for rural sites in Pennsylvania, Georgia, and Tennessee indicate mean $\Delta \mathrm{O}_{3} / \Delta\left(\mathrm{NO}_{\mathrm{y}}-\mathrm{NO}_{\mathrm{x}}\right)$ values of $8.5,11.3$, and $12 \mathrm{~mol} / \mathrm{mol}$, respectively [Trainer et al., 1993; Kleinman et al., 1994; Olszyna et al., 1994]. These values are consistent with our results. Higher OPE values would be expected in the southeastern United States than in the northeast because of higher isoprene and lower $\mathrm{NO}_{\mathrm{x}}$ emissions [Jacob et al., 1993].

Values of $\Delta \mathrm{O}_{3} / \Delta \mathrm{CO}$ and $\Delta \mathrm{O}_{3} / \Delta \mathrm{C}_{2} \mathrm{H}_{2}$ at Harvard Forest decrease from July to September, similarly to $\Delta \mathrm{O}_{3} / \Delta\left(\mathrm{NO}_{\mathrm{y}}-\mathrm{NO}_{\mathrm{x}}\right)$. The mean summertime $\Delta \mathrm{O}_{3} / \Delta \mathrm{CO}$ is $0.35 \mathrm{~mol} / \mathrm{mol}$, typical of observations for other sites in eastern North America [Parrish et al., 1993b; Chin et al., 1994]. Assuming an anthropogenic $\mathrm{NO}_{\mathrm{x}} / \mathrm{CO}$ source ratio of $0.12 \mathrm{~mol} / \mathrm{mol}$ for the eastern United States, including both area and point sources [Environmental Protection Agency, 1995], we derive a corresponding OPE of 2.9. For $\Delta \mathrm{O}_{3} / \Delta \mathrm{C}_{2} \mathrm{H}_{2}$, the mean summertime value is $90 \mathrm{~mol} / \mathrm{mol}$, and the estimated $\mathrm{NO}_{\mathrm{x}} / \mathrm{C}_{2} \mathrm{H}_{2}$ emission ratio is $57 \mathrm{~mol} / \mathrm{mol}$ (mean eastern United States data from the Environmental Protection Agency [1989] cited by McKeen et al. [1991 a], including all anthropogenic sources), corresponding to an OPE of 1.6.

The large difference in the OPE values estimated from $\Delta \mathrm{O}_{3} / \Delta\left(\mathrm{NO}_{\mathrm{y}}-\mathrm{NO}_{\mathrm{x}}\right)$, on the one hand, and from $\Delta \mathrm{O}_{3} / \Delta \mathrm{CO}$ and $\Delta \mathrm{O}_{3} / \Delta \mathrm{C}_{2} \mathrm{H}_{2}$, on the other hand, stresses the potential for bias in the interpretation of these quantities as the OPE. In a threedimensional model for $\mathrm{O}_{3}$ over North America in summer, Chin et al. [1994] obtained a mean OPE of 4.2 for the eastern United States, intermediate between the above estimates. Despite this discrepancy, we will assume for further discussion that the relative seasonal variation of $\Delta \mathrm{O}_{3} / \Delta\left(\mathrm{NO}_{\mathrm{y}}-\mathrm{NO}_{\mathrm{x}}\right)$ reflects the relative seasonal variation of the OPE. Support for this assumption is offered by the strength of the $\mathrm{O}_{3}$ versus $\mathrm{NO}_{y}-\mathrm{NO}_{x}$ correlation, and by the similar relative seasonal variations found for $\Delta \mathrm{O}_{3} / \Delta\left(\mathrm{NO}_{\mathrm{y}}-\mathrm{NO}_{\mathrm{x}}\right)$, $\Delta \mathrm{O}_{3} / \Delta \mathrm{CO}$, and $\Delta \mathrm{O}_{3} / \Delta \mathrm{C}_{2} \mathrm{H}_{2}$ during June-September when data for all three quantities are available.

The seasonal trend of $\Delta \mathrm{O}_{3} / \Delta\left(\mathrm{NO}_{\mathrm{y}}-\mathrm{NO}_{\mathrm{x}}\right)$ reflects mostly the trend in the regional photochemical enhancement of $\mathrm{O}_{3}$ above a background defined by the $y$ intercept of the $\mathrm{O}_{3}$ versus $\mathrm{NO}_{\mathbf{y}}-\mathrm{NO}_{\mathbf{x}}$ 

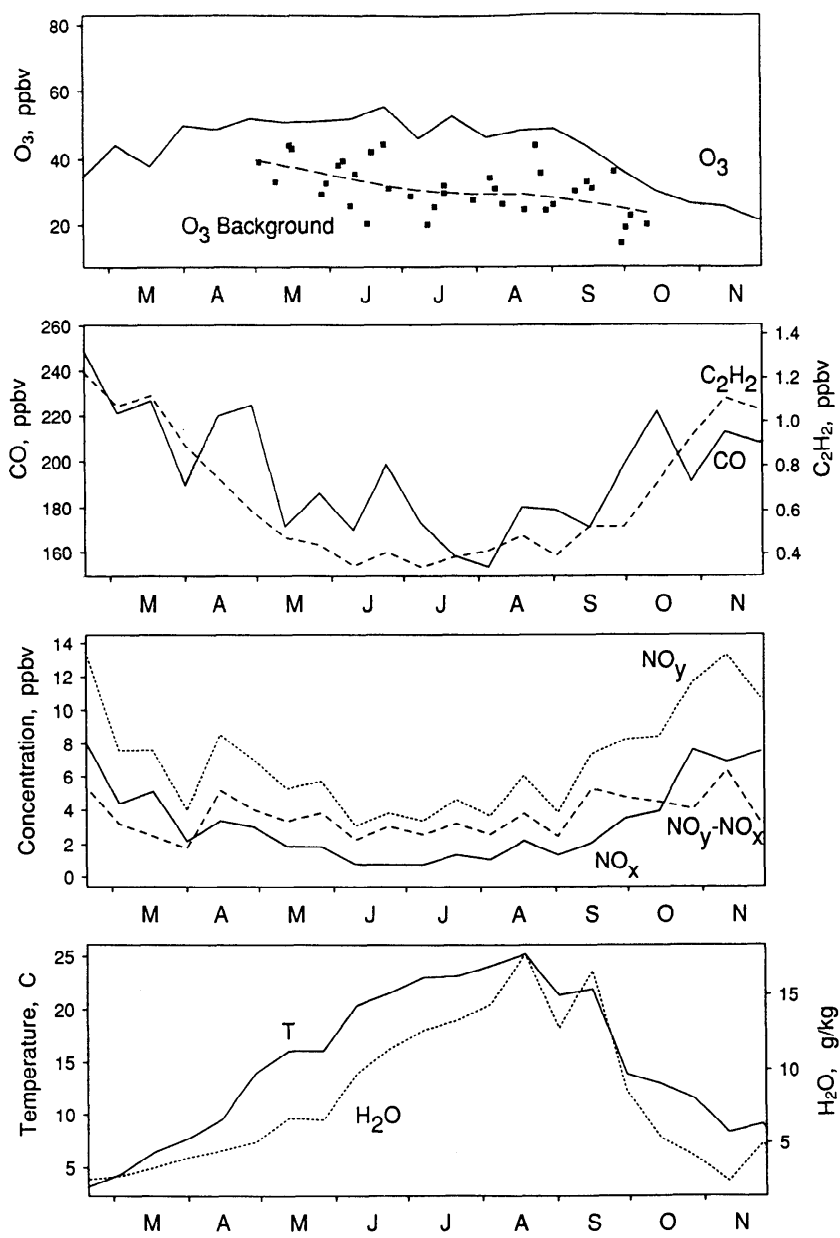

Figure 3. Mean 1990-1994 observations at Harvard Forest at 1100-1700 EST as a function of time of year. The solid squares are the $\mathrm{O}_{3}$ background concentrations defined as the $y$-intercept of the $\mathrm{O}_{3}$ versus $\mathrm{NO}_{\mathrm{y}}-\mathrm{NO}_{x}$ regression line; the corresponding dashed line is a locally weighted regression.

linear regression [Kleinman et al., 1994]. The seasonal variation of $\mathrm{NO}_{y}-\mathrm{NO}_{x}$ is weak in comparison, as seasonal variations of $\mathrm{NO}_{\mathrm{x}}$ and $\mathrm{NO}_{\mathrm{y}}$ tend to cancel (Figure 3; see Munger et al. [1996] for further discussion). The top panel of Figure 3 shows the $\mathrm{O}_{3}$ background values for the individual weeks where $\Delta \mathrm{O}_{3} / \Delta\left(\mathrm{NO}_{\mathrm{y}}-\mathrm{NO}_{\mathrm{x}}\right)$ could be calculated (solid squares). The $\mathrm{O}_{3}$ background decreases from 40 ppbv in early May to $20 \mathrm{ppbv}$ at the end of September, a trend consistent with observed $\mathrm{O}_{3}$ concentrations at remote sites in northern midlatitudes [Logan, 1985]. The high tropospheric background in spring may reflect downwelling of $\mathrm{O}_{3}$ from the stratosphere [Levy et al., 1985], or photochemical production of $\mathrm{O}_{3}$ from precursors stored at high latitudes during the winter months [Liu et al., 1987]. The decrease in the background from spring to summer could reflect in addition a more rapid deposition of $\mathrm{O}_{3}$ to the fully leafed canopy [Munger et al., 1996].

The seasonal decrease in the $\mathrm{O}_{3}$ background from May to September explains why mean $\mathrm{O}_{3}$ concentrations at Harvard Forest peak in May-June, while the enhancement above background peaks in June-August (Figure 3). Observations for Harvard Forest and for nearby Montague, Massachusetts, indicate that although mean $\mathrm{O}_{3}$ concentrations are comparable in May and June, high- $\mathrm{O}_{3}$ episodes are more frequent in June [Logan, 1989; Munger et al., 1996], consistent with a higher OPE in June.

\section{Interpretation}

The seasonal variation of the OPE derived from the Harvard Forest data appears at first look to be in phase with solar radiation and temperature. There are however some differences. The OPE is lower in May than in August, even though solar radiation is slightly higher in May. Temperatures increase from June to August (Figure 3, bottom panel) but the OPE does not. The closest coincidence of the seasonal variation of the OPE appears to be with isoprene emission. Continuous observations of isoprene emission at Harvard Forest in 1995 (A.H. Goldstein, unpublished data) show that isoprene emission is nil until early June; rises from early June through the end of June; declines through September; and shuts off abruptly in mid-September. Goldstein [1994] found similar seasonal cycles of isoprene emission for 1992-1994, overlapping our analysis period, but these data are qualitative only and cannot be used for correlation with our OPE values. It is well known that isoprene emission depends on temperature and solar radiation [e.g., Guenther et al., 1995]. However, the seasonal delay of isoprene emission until early June cannot be explained from these dependences and implies that leaves do not emit isoprene until they are fully expanded [Goldstein, 1994]. Previous measurements of the seasonal cycle of isoprene for a lowelevation aspen forest in Colorado [Monson et al., 1994] and for a boreal forest in Ontario [Jobson et al., 1994] also indicate a sharp onset of isoprene emission in June (after leaves are fully expanded), a decline starting in July-August, and a complete shut-off during September.

A strong dependence of the OPE on isoprene would be expected from current understanding of tropospheric chemistry, as illustrated by the photochemical model calculations presented in the next section. Isoprene is the principal hydrocarbon precursor of $\mathrm{O}_{3}$ over the eastern United States in summer [McKeen et al., 1991a]. The presence of isoprene under $\mathrm{NO}_{\mathrm{x}}$-limited conditions increases the OPE by depleting $\mathrm{OH}$ and hence slowing down the oxidation of $\mathrm{NO}_{\mathbf{x}}$ to $\mathrm{HNO}_{3}$ [Lin et al., 1988; Fan et al., 1994]. An additional factor that may contribute to the seasonal decrease in the OPE from July to October is the decreasing supply of the $\mathrm{HO}_{\mathbf{x}}$ radicals $\left(\mathrm{OH}\right.$ and peroxy) that drive $\mathrm{O}_{3}$ production. Jacob et al. [1995] found evidence for a seasonal transition from $\mathrm{NO}_{\mathrm{x}}-$ to hydrocarbon-limited $\mathrm{O}_{3}$ production over the eastern United States in September, reflecting a decline of the $\mathrm{HO}_{\mathbf{x}}$ supply down to levels that can be titrated by $\mathrm{NO}_{\mathrm{x}}$ emission. Such a transition in photochemical regime would result in a large drop of the OPE [Sillman, 1995]. The seasonal decrease of $\mathrm{OH}$ concentrations also increases the importance of nighttime oxidation as a sink for $\mathrm{NO}_{\mathrm{x}}$ [Dentener and Crutzen, 1993; Munger et al., 1996], further decreasing the OPE.

It is well known that $\mathrm{O}_{3}$ concentrations in the eastern United States are correlated with temperature [National Research Council, 1991]. This correlation appears to reflect, in part, the dependences of isoprene emission and peroxyacetylnitrate (PAN) stability on temperature [Cardelino and Chameides, 1990; Sillman and Samson, 1995], but also the association of high temperatures with stagnation episodes [Jacob et al., 1993] and sunny skies [Walcek and Yuan, 1995]. We show in Figure 4 the relationship of $\Delta \mathrm{O}_{3} / \Delta\left(\mathrm{NO}_{\mathrm{y}}-\mathrm{NO}_{\mathrm{x}}\right)$ with temperature in the Harvard Forest data for individual weeks. Here temperature is the weekly average at 1100-1700 EST (results are similar when maximum weekly temperature is used). We find a marked increase of the OPE with temperature that appears attributable at least, in part, to isoprene; weekly temperatures in the $20^{\circ}-25^{\circ} \mathrm{C}$ range are associated with lower OPE values when outside of the seasonal time window for isoprene emission. The model of Sillman and Samson [1995] for 


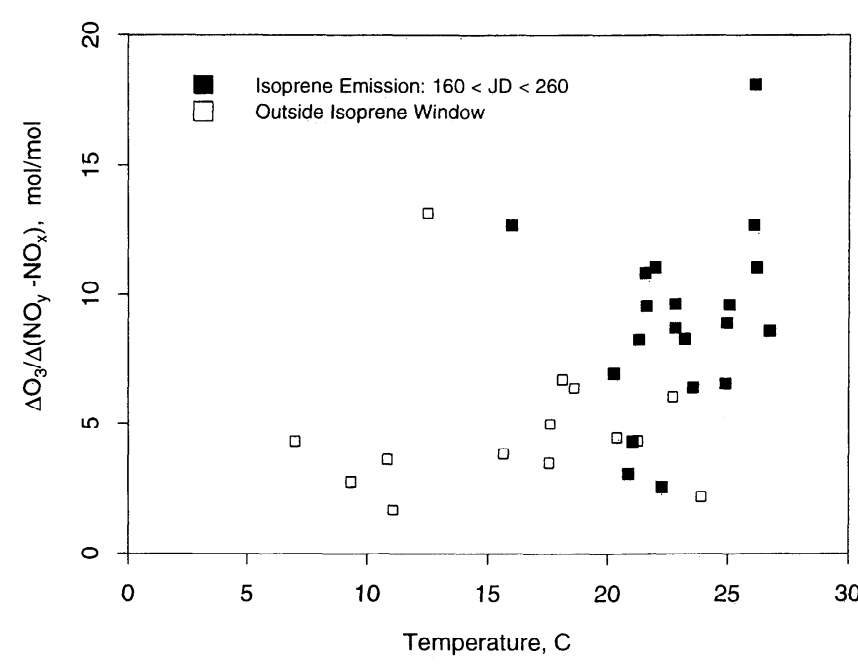

Figure 4. Relationship of $\Delta \mathrm{O}_{3} / \Delta\left(\mathrm{NO}_{\mathrm{y}}-\mathrm{NO}_{\mathrm{x}}\right)$ with the weckly average temperature at 1100-1700 EST. JD is Julian (calendar) day. Solid squares identify weeks within the June 10 - September 15 seasonal time window for isoprene emission at Harvard Forest [Goldstein, 1994; A.H. Goldstein, unpublished data].

rural photochemistry in the eastern United States indicates an increase of $\Delta \mathrm{O}_{3} / \Delta\left(\mathrm{NO}_{\mathrm{y}}-\mathrm{NO}_{\mathrm{x}}\right)$ from 5.0 to $7.5 \mathrm{~mol} / \mathrm{mol}$ as temperature increases from $293 \mathrm{~K}$ to $308 \mathrm{~K}$, including effects from both isoprene emission and PAN stability, but the results in Figure 4 indicate a steeper increase. The isoprene emissions assumed by Sillman and Samson [1995] are about 3 times lower than recommended in the recent inventories of Geron et al. [1994] and Guenther et al. [1995], possibly explaining the difference.

According to photochemical models, the OPE should decrease with increasing $\mathrm{NO}_{\mathrm{x}}$ above $0.3 \mathrm{ppbv}$ [Lin et al., 1988]. We find no significant correlation between $\Delta \mathrm{O}_{3} / \Delta\left(\mathrm{NO}_{\mathrm{y}}-\mathrm{NO}_{\mathrm{x}}\right)$ and $\mathrm{NO}_{\mathrm{x}}$ in the Harvard Forest data for June-August $(r=-0.15)$. This lack of correlation could, however, reflect the fact that the $\mathrm{O}_{3}$ enhancements in polluted air parcels are due to accumulation over several days [Kleinman et al., 1994], while the lifetime of $\mathrm{NO}_{\mathrm{x}}$ is less than a day. Perhaps more meaningful is that we find no significant correlation of $\Delta \mathrm{O}_{3} / \Delta\left(\mathrm{NO}_{\mathrm{y}}-\mathrm{NO}_{\mathrm{x}}\right)$ with $\mathrm{CO}$, a long-lived tracer of pollution. There is a significant negative correlation with $\mathrm{NO}_{\mathrm{y}}(r$ $=-0.52$ ), which could, however, reflect the effect of $\mathrm{NO}_{\mathrm{y}}$ deposition.

\section{Photochemical Model Calculations}

We used a one-dimensional photochemical model for the continental boundary layer over the eastern United States to support our analysis of the factors controlling the seasonal variation of the OPE. The model has been described previously by Jacob et al. [1995]. It resolves the boundary layer with six gridpoints extending up to $1.8 \mathrm{~km}$. Vertical transport is represented by diurnally varying eddy diffusion coefficients. The gas phase $\mathrm{HO}_{\mathrm{x}}-\mathrm{NO}_{\mathrm{x}}-$ hydrocarbon chemical mechanism is based on recent compilations of laboratory data. Hydrolysis of $\mathrm{N}_{2} \mathrm{O}_{5}$ in aerosols is included with a rate constant of $1 \times 10^{-4} \mathrm{~s}^{-1}$. Ultraviolet intensities are computed assuming $30 \%$ opaque cloud cover. The deposition velocity of $\mathrm{O}_{3}$ at $10 \mathrm{~m}$ altitude is $0.5 \mathrm{~cm} \mathrm{~s}^{-1}$ in the day and $0.1 \mathrm{~cm} \mathrm{~s}^{-1}$ at night. The deposition of $\mathrm{HNO}_{3}$ is limited by the rate of turbulent diffusion to the surface, and is sufficiently fast that conversion to
$\mathrm{HNO}_{3}$ is a terminal sink for $\mathrm{NO}_{\mathrm{x}}$. Anthropogenic emissions of $\mathrm{NO}_{\mathrm{x}}$ and hydrocarbons are mean values for the eastern United States as given by McKeen et al. [1991a]. Fixed concentrations are assumed for $\mathrm{CO}(200 \mathrm{ppbv})$ and $\mathrm{CH}_{4}(1700 \mathrm{ppbv})$. Low concentrations (including 30 ppbv $\mathrm{O}_{3}$ ) are specified as upper boundary conditions at $1.8 \mathrm{~km}$ and are also used as initial conditions.

We examined the seasonality of the OPE in the model by conducting a series of 7-day simulations for conditions representative of individual months from March to October. Solar declination was specified for the middle of the month. Temperature and dew point were specified from the data in Figure 3. Isoprene emission was included from June to September with a 24-hour average flux of $2 \times 10^{11}$ molecules $\mathrm{cm}^{-2} \mathrm{~s}^{-1}$ [Guenther et al., 1995], varying with time of day as described by Jacob et al. [1989]. The isoprene emission in the June-September window was held constant, that is, it was not adjusted for month-to-month changes in temperature, in order to isolate the effect of isoprene emission from other temperature-related effects. The afternoon mixed layer depth varied from $1.3 \mathrm{~km}$ in March to $1.7 \mathrm{~km}$ in April-September to 1.5 $\mathrm{km}$ in October [Holzworth, 1967].

Figure 5 shows the time series of $\mathrm{O}_{3}, \mathrm{NO}_{\mathrm{x}}$, and $\mathrm{NO}_{\mathrm{y}}-\mathrm{NO}_{\mathrm{x}}$ concentrations simulated by the model in July. Also shown is the time series of the net OPE defined as the ratio of net chemical pro-
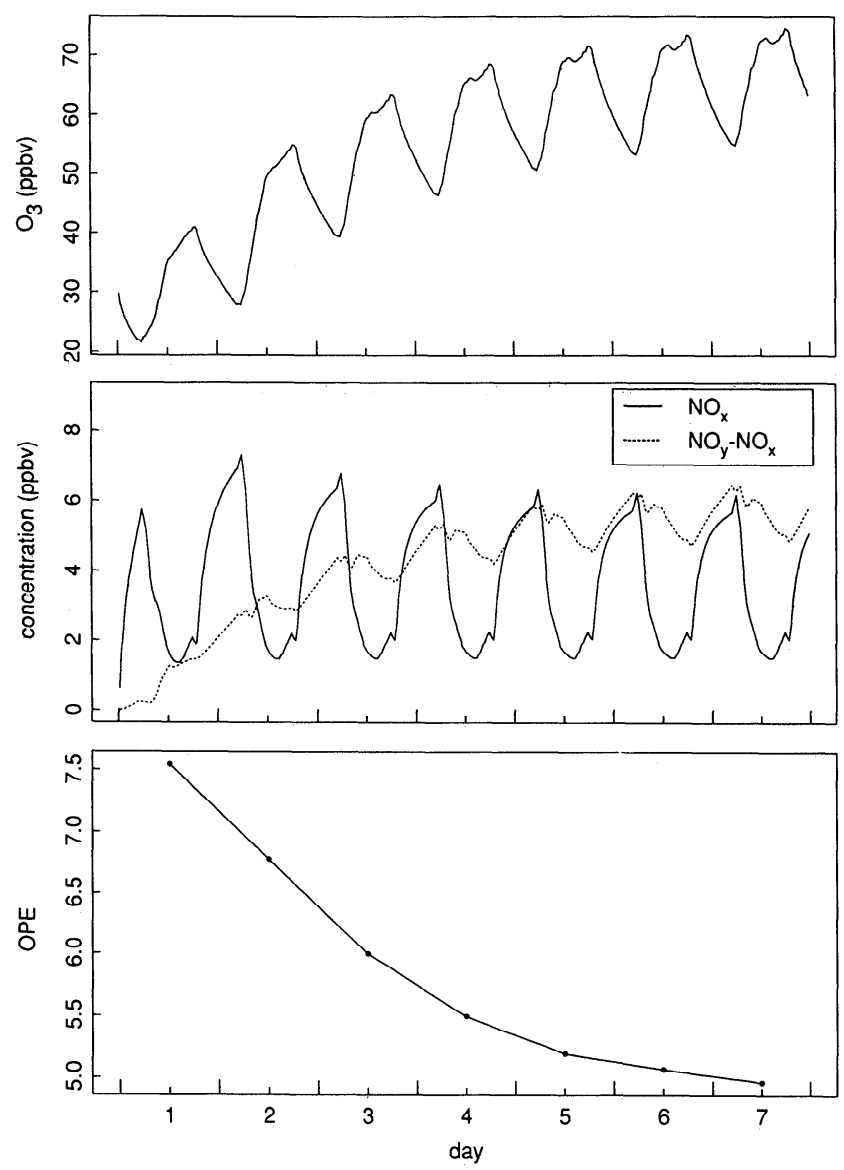

Figure 5. Surface air concentrations of $\mathrm{O}_{3}, \mathrm{NO}_{x}$, and $\mathrm{NO}$ y calculated with a one-dimensional photochemical model for Harvard Forest in July, and net OPE for successive days calculated as the ratio of the net chemical production of $\mathrm{O}_{3}$ to the net chemical loss of $\mathrm{NO}_{\mathbf{x}}$ averaged over 24 hours in the $0-1.8 \mathrm{~km}$ column. 


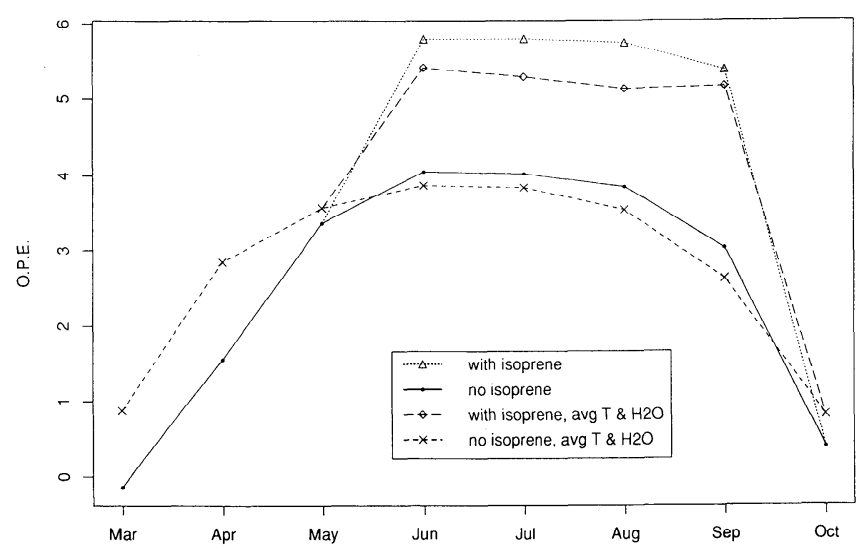

Figure 6. Seasonal variation of the net OPE computed in the one-dimensional model. The solid line shows results from the standard simulation accounting for seasonal changes of solar declination, temperature, and humidity, but without isoprene emission. The dotted line shows the effect of including isoprene emission at a constant value from June to September. The dashed lines show results of simulations with temperature and specific humidity held constant from March to October at their mean values for the period, without isoprene emission (short dashes) and with isoprene emission from June to September (long dashes).

duction of $\mathrm{O}_{3}$, (P-L) $)_{3}$, to net chemical loss of $\mathrm{NO}_{x}$, $(\mathrm{L}-\mathrm{P})_{\mathrm{NO}_{\mathrm{x}}}$, averaged over 24 hours for each individual day. The OPE decreases from 7.5 to 5.0 over the 7 days of simulation, principally because of rising $\mathrm{O}_{3}$ concentrations and hence faster $\mathrm{O}_{3}$ loss. We choose to define the model OPE representative of the 7-day simulation as the ratio of the 7-day average values of $(\mathrm{P}-\mathrm{L})_{\mathrm{O}_{3}}$ and $(\mathrm{L}$ $\mathrm{P})_{\mathrm{NO}_{\mathrm{x}}}$.

Figure 6 shows the seasonal variation of the OPE computed in the above manner. The OPE is negative in March as photochemistry is a net sink for $\mathrm{O}_{3}$. It rises to a maximum value of 5.7 in June-September, and decreases abruptly in October back to negative values. The summertime OPE in the model is $30 \%$ lower than the mean observed value of $\Delta \mathrm{O}_{3} / \Delta\left(\mathrm{NO}_{\mathrm{y}}-\mathrm{NO}_{\mathrm{x}}\right)$ at Harvard Forest; the difference could be due to a number of factors as discussed above. The sharp rise in the model OPE from May to June is consistent with that observed for $\Delta \mathrm{O}_{3} / \Delta\left(\mathrm{NO}_{\mathrm{y}}-\mathrm{NO}_{\mathrm{x}}\right)$, but the model does not capture the observed decrease of $\Delta \mathrm{O}_{3} / \Delta\left(\mathrm{NO}_{\mathrm{y}}-\mathrm{NO}_{\mathrm{x}}\right)$ from July to September.

The principal factors controlling the seasonal variation of the OPE in the model are isoprene emission, UV radiation, and humidity. Figure 6 shows the results of sensitivity simulations exploring the role of these different factors. The simulations without isoprene emission show little increase in OPE from May to June, but a significant OPE decline starting in August. The decline reflects the decreasing supply of $\mathrm{HO}_{\mathrm{x}}$ radicals, forcing a transition to a hydrocarbon-limited regime. This transition is delayed to October when isoprene is present [Jacob et al., 1995]. Observations of the seasonal cycle of isoprene [Goldstein, 1994; Jobson et al., 1994; Monson et al., 1994] all indicate a decrease in emission from July to September, which could perhaps explain the seasonal decrease of the OPE at Harvard Forest. Even in the absence of isoprene, OPE values in the model are higher in September than in
April, due to the higher absolute humidity in September and hence the larger source of $\mathrm{HO}_{x}$ radicals. In a sensitivity calculation with temperature and absolute humidity taken to be seasonally invariant (short-dashed line in Figure 6), the OPE values in April and September are similar.

\section{Conclusions}

Weekly values of the net $\mathrm{O}_{3}$ production efficiency per unit $\mathrm{NO}_{x}$ (OPE) were estimated at Harvard Forest from a 5-year record of $\mathrm{O}_{3}, \mathrm{NO}_{\mathrm{x}}, \mathrm{NO}_{\mathrm{y}}, \mathrm{CO}$, and $\mathrm{C}_{2} \mathrm{H}_{2}$ concentrations. The data show a sharp rise in the OPE from May to June-July, which is attributed to onset of isoprene emission, and a gradual decrease from July to October. Our results support photochemical model predictions that isoprene is a major factor enhancing $\mathrm{O}_{3}$ production per unit $\mathrm{NO}_{x}$. Three-dimensional models for the eastern United States in summer indicate that isoprene emission increases surface $\mathrm{O}_{3}$ levels by $5-15$ ppbv relative to isoprene-free conditions [McKeen el al., 1991b; Roselle et al., 1991; Jacob et al., 1993]. Isoprene emission in these models appears to be underestimated by about a factor of 3 relative to more recent estimates [Geron et al., 1994; Guenther et al., 1995], so that the magnitude of the $\mathrm{O}_{3}$ enhancement associated with isoprene would be underestimated. The photochemical model calculations presented in this paper, including isoprene emission from Guenther et al. [1995], indicate a 50\% increase in OPE in summer due to isoprene emission. Because of the importance of isoprene for $\mathrm{O}_{3}$ production and for other aspects of tropospheric photochemistry [Fehsenfeld et al., 1992], there is a clear need to better understand the factors controlling its emission by vegetation.

The seasonal variations derived in this work for the OPE and for the regional $\mathrm{O}_{3}$ background can be used to interpret the seasonal variation of $\mathrm{O}_{3}$ concentrations observed in the eastern United States. The high- $\mathrm{O}_{3}$ season extends from May to September [Logan, 1985; Vukovich, 1994]; the trend within this time window varies considerably from year to year and from site to site but there is a tendency for earlier seasonal maxima in the northeastern United States than in the southeast [Vukovich, 1994]. Our analysis suggests that the extent of the high- $\mathrm{O}_{3}$ season is largely defined by the seasonal window of isoprene emission (June-September). The later seasonal maxima of $\mathrm{O}_{3}$ in the southeastern United States than in the northeast may be explained by a later senescence of vegetation. The relatively high mean $\mathrm{O}_{3}$ concentrations observed in May, before the onset of isoprene emission, appear to be due in part to an elevated tropospheric background.

Acknowledgments. This work was supported by the National Science Foundation (NSF-ATM-93-04217), by the National Aeronautics and Space Administration (NASA-NAGW 3082), and by the Department of Energy (through NIGEC Cooperative Agreement DE-FC0390ER61010).

\section{References}

Cardelino, C.A., and W.L. Chameides, Natural hydrocarbons, urbanization, and urban ozonc, J. Geophys. Res., 95, 13,97113,979, 1990.

Chameides, W.L., et al., Ozone precursor relationships in the ambient atmosphere, J. Geophys. Res., 97, 6037-6055, 1992. 
Chin, M., D.J. Jacob, J.W. Munger, D.D. Parrish, and B.G. Doddridge, Relationship of ozone and carbon monoxide over North America, J. Geophys. Res., 99, 14,565-14,573, 1994.

Dentener, F.J., and P.J. Crutzen, Reaction of $\mathrm{N}_{2} \mathrm{O}_{5}$ on tropospheric acrosols: Impact on the global distributions of $\mathrm{NO}_{\mathbf{x}}, \mathrm{O}_{3}$, and $\mathrm{OH}$, J. Geophys. Res., 98, 7149-7163, 1993.

Environmental Protection Agency (EPA), The 1985 NAPAP cmission inventory (version 2): Development of the annual data and modeler's tapes, Rep. EPA-600/7-89-0/2a, Environ. Prot. Agency, Research Triangle Park, N.C., 1989.

Environmental Protection Agency (EPA), National air pollutant emission Irends, 1900-1994, Rep. EPA-454/R-95-011, Environ. Prot. Agency, Rescarch Triangle Park, N.C., 1995.

Fan, S.-M., D.J. Jacob, D.L. Mauzerall, J.D. Bradshaw, S.T. Sandholm, D.R. Blake, R.W. Talbot, G.L. Gregory, and C.W. Sachse, Origin of tropospheric $\mathrm{NO}_{x}$ over subarctic eastern Canada in summer, J. Geophys. Res., 99, 16,867-16,877, 1994.

Fehsenfeld, F., et al., Emissions of volatile organic compounds from vegetation and the implications for atmospheric chemistry, Global Biogeochem. Cycles, 6, 389-430, 1992.

Geron, C.D., A.B. Guenther, and T.E. Pierce, An improved model for estimating emissions of volatile organic compounds from forests in the eastern United States, J. Geophys. Res., 99, 12,773-12,791, 1994.

Goldstein, A.H., Non-methane hydrocarbons above a midlatitude forest: Biogenic emissions and scasonal concentration variations, Ph.D. thesis, Harvard University, Cambridge, Mass., 1994.

Goldstein, A.H., S.C. Wofsy, and C.M. Spivakovsky, Seasonal variations of nonmethane hydrocarbons in rural New England: Constraints on $\mathrm{OH}$ concentrations in northern mid-latitudes, $J$. Geophys. Res., 100, 21,023-21,033, 1995.

Guenther, A., et al., A global model of natural volatile organic compound emissions, J. Geophys. Res., 100, 8873-8892, 1995.

Hirsch, R.M., and E.J. Gilroy, Methods of fitting a straight line to data: Examples in water resources, Water Res. Bull., 20, 705 711,1984

Holzworth, G.C., Mixing depths, wind speeds and air pollution potentials for selected locations in the United States, J. Appl. Meteorol., 6, 1039-1044, 1967.

Jacob, D.J., S. Sillman, J.A. Logan, and S.C. Wofsy, Leastindependent-variables method for simulations of tropospheric ozone, J. Geophys. Res., 94, 8497-8509, 1989.

Jacob, D.J., J.A. Logan, G.M. Gardner, R.M. Yevich, C.M. Spivakovsky, S.C. Wofsy, S. Sillman, and M.J. Prather, Factors regulating ozone over the United States and its export to the global atmosphere, J. Geophys. Res., 98, 14,817-14,826, 1993.

Jacob, D.J., L.W. Horowitz, J.W. Munger, B.G. Hcikes, R.R. Dickerson, R.S. Artz, and W.C. Keene, Seasonal transition from $\mathrm{NO}_{\mathrm{x}}$ - to hydrocarbon-limited ozone production over the eastern United States in September, J. Geophys. Res., 100, 9315-9324, 1995.

Jobson, B.T., Z. Wu, H. Niki, and L.A. Barric, Scasonal trends of isoprene, $\mathrm{C}_{2}-\mathrm{C}_{5}$ alkanes, and acetylene at a remote boreal site in Canada, J. Geophys. Res., 99, 1589-1599, 1994.

Kleinman, L., et al., Ozone formation at a rural site in the southeastern United States, J. Geophys. Res., 99, 3469-3482, 1994.

Levy, H. II, J.D. Mahlman, W.J. Moxim, and S.C. Liu, Tropospheric ozone: The role of transport, J. Geophys. Res., 90, 3753-3772, 1985 .
Lin, X., M. Trainer, and S.C. Liu, On the nonlinearity of tropospheric ozonc production, J. Geophys. Res., 93, 15,879-15,888, 1988.

Liu, S.C., M. Trainer, F.C. Fehsenfeld, D.D. Parrish, E.J. Williams, D.W. Fahey, G. Hubler, and P.C. Murphy, Ozone production in the rural troposphere and the implications for regional and global ozone distributions, J. Geophys. Res., 92, 4191-4207, 1987.

Logan, J.A., Tropospheric ozone: Seasonal behavior, trends and anthropogenic influence, J. Geophys. Res., 9l, 10,463-10,482, 1985.

Logan, J.A., Ozone in rural areas of the United States, J. Geophys. Res., 94, 8511-8532, 1989.

McKeen, S.A., E.-Y. Hsie, M. Trainer, R. Tallamraju, and S.C. Liu, A regional model study of the ozone budget in the eastern United States, J. Geophys. Res., 96, 10,809-10,845, 1991 a.

McKeen, S.A., E.-Y. Hsic, and S.C. Liu, A study of the dependence of rural ozone on ozone precursors in the Eastern United States, J. Geophys. Res., 96, 15,377-15,394, 1991 b.

Monson, R.K., P.C. Harley, M.E. Litvak, M. Wildermuth, A.B Guenther, and P.R. Zimmenman, Environmental and development controls over the seasonal pattern of isoprene emission from aspen leaves, Oecologia, 99, 260-270, 1994.

Munger, J.W., S.C. Wofsy, P.S. Bakwin, S.-M. Fan, M.L. Goulden, B.C. Daube, A.H. Goldstein, K. Moore, and D. Fitzjarrald, Atmospheric deposition of reactive nitrogen oxides and ozone in a temperate deciduous forest and a sub-arctic woodland, J. Geophys. Res., in press, 1996.

National Research Council (NRC), Rethinking the Ozone Problem in Urban and Regional Air Pollution, Natl. Acad. Press, Washington, D.C., 1991.

Olszyna, K.J., E.M. Bailey, R. Simonaitis, and J.F. Meagher, $\mathrm{O}_{3}$ and $\mathrm{NO}_{\mathrm{y}}$ relationships at a rural site, J. (jeophys. Res., 99, 14,557-14,563, 1994

Parrish, D.D., Carbon monoxide and light alkanes as tropospheric tracers of anthropogenic ozone, in The Tropospheric Chemistry of Ozone in the Polar Regions, NATO ASI Ser., 17 edited by H. Niki and K.H. Becker, Springer-Verlag, New York, 1993.

Parrish, D.D., et al., The total reactive oxidized nitrogen levels and the partitioning between the individual species at six rural sites in eastern North America, J. Geophys. Res., 98, 2927-2939, 1993a.

Parish, D.D., J.S. Holloway, M. Trainer, P.C. Murphy, G.L. Forbes, and F.C. Fehsenfeld, Export of North American ozone pollution to the North Allantic Ocean, Science, 259, 1436-1439, 1993b.

Roselle, S.J., T.E. Pierce, and K.L. Schere, The sensitivity of regional ozone modeling to biogenic hydrocarbons, J. Geophys. Res., 96, 7371-7394, 1991

Sillman, S., The use of $\mathrm{NO}_{y}, \mathrm{H}_{2} \mathrm{O}_{2}$ and $\mathrm{HNO}_{3}$ as indicators of ozone- $\mathrm{NO}_{\mathrm{x}}$-hydrocarbon sensitivity in urban locations, J. (jeophys. Res., 100, 14,175-14,188, 1995.

Sillman, S., and P.J. Samson, Impact of temperature on oxidant photochemistry in urban, polluted rural and remote environments,J. Geophys. Res., 100, 11,497-11,508, 1995.

Sillman, S., J.A. Logan, and S.C. Wofsy, The sensitivity of ozone to nitrogen oxides and hydrocarbons in regional ozone episodes, J. Geophys. Res., 95, 1837-1852, 1990.

Trainer, M., et al., Correlation of ozone with $\mathrm{NO}_{y}$ in photochemically aged air, J. Geophys. Res., 98, 2917-2925, 1993.

Vukovich, F.M., Boundary layer ozone variations in the eastern United States and their association with meteorological varia- 
tions: Long-term variations, J. Geophys. Res., 99, 16,83916,850, 1994.

Walcek, C.J., and H.-H. Yuan, Calculated influence of temperature-related factors on ozone formation rates in the lower troposphere, J. Appl. Meteorol., 34, 1056-1069, 1995.

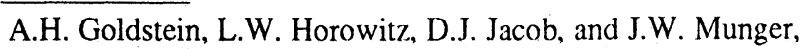
Harvard University, Department of Earth and Planetary Sciences,
Pierce Hall, 29 Oxford Street, Cambridge, MA 02138. (e-mail: ahg@io.harvard.edu; lwh@io.harvard.edu; djj@io.harvard.edu; jwm@io.harvard.edu)

A.I. Hirsch, University of California, Department of Geoscience, Irvine, CA 92717. (e-mail: hirsch@essgrad.ps.uci.edu)

(Received September 16, 1995; revised January 30, 1996; accepted January 30, 1996.) 